\title{
Bogusław Nierenberg
}

Uniwersytet Jagielloński

ORCID: 0000-0002-2178-2406

boguslaw.nierenberg@uj.edu.pl

\section{Z DOŚWIADCZEŃ NSZZ "SOLIDARNOŚĆ" NA OPOLSZCZYŹNIE 1980-1981. TRZY STUDIA PRZYPADKU W UJĘCIU MEDIALNYM}

\author{
Abstract \\ FROM THE EXPERIENCES OF SOLIDARITY IN OPOLE SILESIA 1980-1981: \\ THREE CASE STUDIES FROM THE PERSPECTIVE OF MEDIA
}

The article is a contribution to the understanding of not only the organisational and social phenomenon of Solidarity in Poland in the years 1980-81, but also of its media image. The research presented in the article was based on the analysis of three case studies. The author took active part in each of them. The studied cases concern the region of Opole Silesia and pertain to one of the first strikes that took place in this part of the country in that time; a radio programme in which for the first time in the Polish People's Republic, a local historian reminds about the significance of Poland regaining independence in 1918 and the issues concerning the general strike which was to take place in March 1918, according to the then chairperson of the Regional Board of Solidarity in Opole Silesia.

The analysis of the three cases performed against the backdrop of the events that took place in that time leads the author to reflect that there are moments in the existence of nations, but also in the structures within which they function, when the attitude of the people who participate in them becomes highly important.

Keywords: Solidarity, organisational structures, people's attitudes, media portrayal of events

\section{Uwagi wstępne i przesłanki badawcze}

Kiedy w sierpniu 1980 roku rozpoczyna się najpierw w Gdańsku, a potem w reszcie kraju karnawał Solidarności, nie wszyscy przyjmują go z radością. Są grupy zawodowe, które obawiają się utraty rozmaitych przywilejów. Wśród nich byli też 
dziennikarze. W zasadzie wszystkie publikatory w tamtym czasie musiały mieć partyjne imprimatur. W jednych mediach można było powiedzieć trochę więcej, w innych trochę mniej, ale nad wszystkim czuwał Wielki Brat, czyli komunistyczna cenzura.

Władza komunistyczna zdawała sobie doskonale sprawę, że „z niewolnika nie ma robotnika”, więc przekupywała rozmaite grupy społeczne pożądanymi wówczas „dobrami”. Dziennikarze należeli do grona tych uprzywilejowanych, ale stopień uprzywilejowania zależał od stopnia służalczości. Ci, którzy żarliwie wychwalali komunistyczną władzę i uprawiali nowomowę w duchu miłym komunistycznej wierchuszce, mogli liczyć, że w pierwszej kolejności dostaną przydział na mieszkanie, talon na samochód, skierowanie na zagraniczne wczasy w jednym $z$ „demoludów”. Ci, którzy zajmowali się tematyką społeczną bądź kulturalną, byli mniej hojnie obdarowywani, albo zgoła wcale. Jeden z moich radiowych kolegów, poirytowany tym rozdawnictwem, napisał podanie do redaktora naczelnego, by dali mu talon na rower. Talonu nie dostał, ale za to podpadł władzy. I co ciekawe, relatywna wolność wypowiedzi w mediach była wprost proporcjonalnie skorelowana $\mathrm{z}$ siłą władzy komunistycznej. Im władza silniejsza, tym mniej było wolno i na odwrót.

Lata 70. XX wieku były w Polsce czasem rosnącej konsumpcji. W porównaniu z siermiężnością lat 60. wydawało się, że Polska wkracza do normalnego, europejskiego świata. Pojawiły się zachodnie towary, rosły aspiracje. Władza komunistyczna skrzętnie skrywała przed obywatelami, że to wszystko jest na kredyt. Taka gospodarka musiała się zawalić, otwarte było jedynie pytanie kiedy. Komuniści starali się zaklinać rzeczywistość. W 1976 roku do Konstytucji PRL wprowadzono zapis o przewodniej roli partii komunistycznej i przyjaźni ze Związkiem Radzieckim. Wywołało to protest grupy intelektualistów, którzy wskazywali, że „przewodniej roli partii” nie da się pogodzić z wolnością sumienia, wyznania, a także słowa ${ }^{2}$. Taki stan rzeczy sprzyjał rozwojowi wydawnictw tzw. drugiego obiegu. W Polsce publikacje poza cenzurą zaczęły się ukazywać już w latach 60 . XX wieku, jednak nasilenie tego procesu to druga połowa lat 70., kiedy to za sprawą Ruchu Praw Człowieka i Obywatela oraz Komitetu Obrony Robotników powstaje, założona przez Mirosława Chojeckiego, Niezależna Oficyna Wydawnicza (NOWa) ${ }^{3}$. Ten proces był kontynuowany po wprowadzeniu stanu wojennego. Wielu dziennikarzy zwolnionych $\mathrm{w}$ stanie wojennym $\mathrm{z}$ partyjnych mediów szukało pracy w nielicznych redakcjach, działających poza zasięgiem komunistycznej władzy, na przykład w prasie kościelnej. Wielu z nich publikowało także $\mathrm{w}$ tzw. drugim obiegu, a jeszcze inni szukali

1 Tak określano kraje bloku komunistycznego, będącego pod dominacją Związku Radzieckiego; nazwa „demolud” jest sarkastycznym skrótem od określenia „demokracja ludowa”.

2 List protestacyjny do władz komunistycznych podpisało 59 osób, tej miary co: Wisława Szymborska, Adam Zagajewski, Stanisław Barańczak, Stefan Kisielewski, Jan Józef Lipski, Jan Olszewski i inni; źródło: https://wpolityce.pl/historia/281194-40-lat-temu-uchwalono-poprawkido-konstytucji-prl-wprowadzajac-zapis-o-przyjazni-z-zsrr (dostęp: 11.01.2020).

3 Zob. https://pl.wikipedia.org/wiki/Wydawnictwo_podziemne (dostęp: 4.01.2020). 
źródeł utrzymania poza dziennikarstwem. Uważna lektura publikacji ukazujących się poza cenzurą pozwala prześledzić zmianę nastrojów i postaw społecznych. Ten stan rzeczy sprawiał, że diagnoza Stefana Kisielewskiego: „Niepełna, niecałościowa informacja, czyli dezinformacja, czyli w rezultacie kłamstwo praktykowane na co dzień, wrasta nam w krew, staje się drugą naturą, ba, nieraz wręcz powinnością moralną czy narodową"4 - traciła powoli na aktualności. Ten sam Kisiel zdawał sobie doskonale sprawę, jak istotny jest każdy, nawet drobny sprzeciw wobec komunistycznej dyktatury: „Opozycja bzykającego komara też jest opozycją”. Komunistyczny reżim to słabł, to się podnosił, ale wciąż trwał.

W książce zatytułowanej Na to, żeby komuś odebrać wolność, musi być sąd, na którą złożyły się moje reportaże radiowe z przełomu lat 70. i 80., napisałem, iż:

Widać w nich losy pojedynczych ludzi wtłoczonych w machinę Historii, którzy na przekór dyktaturze komunistycznej starają się znaleźć swoje miejsce na ziemi. Widać rozmaite upiory wyłażące z ciemnych kątów, widać paradoksy, pośród których przyszło żyć Polakom w tamtych czasach. Dotyczyło to także autora zamieszczonych w tym tomie reportaży. To był czas, w którym cenzura stała na straży komunistycznych pryncypiów. Jedyne, czego bała się komunistyczna władza, to gniew obywateli. Kiedy narastało społeczne niezadowolenie, słabła cenzorska czujność 6 .

Koniec lat 70. XX wieku to koniec bałamutnego snu o „dziesiątej potędze świata" i nasilające się kłopoty gospodarcze. Do tego ojczyznę odwiedza wybrany w 1978 roku papież Jan Paweł II, którego pielgrzymka do Polski gromadzi setki tysięcy wiernych. To wszystko sprawia, że Polacy coraz głośniej upominają się o godne życie. I to w każdym wymiarze: ekonomicznym, społecznym i kulturowym. Tak rodzi się Solidarność. Kształtowanie się struktur związkowych wnikliwie zbadała i opisała Anna Modzelewska w swej pracy doktorskiej zatytułowanej Struktury organizacyjne NSZZ „Solidarnośćc w latach 1980-19897.

Nie przypadkiem przywołałem tę pracę, bowiem wydawać by się mogło, że doświadczenie Solidarności było tak silne, iż odcisnęło swój ślad we wszystkich naukach społecznych, a i nauki humanistyczne też znalazły w nim interesujące obszary badawcze. Zatem literatura naukowa opisująca Solidarność w jej rozmaitych ujęciach i wymiarach winna być nad wyraz bogata i różnorodna. Tymczasem różnie to bywa w konkretnych dziedzinach. Jest sporo publikacji będących opisami historycznymi, natomiast w kwestiach dotyczących innych obszarów badań już takiego bogactwa nie ma. Dowodzi tego kwerenda literatury odnoszącej się do rozmaitych aspektów działania Solidarności i ich następstw.

4 Zob. https://pl.wikiquote.org/wiki/Stefan_Kisielewski (dostęp: 6.01.2020).

5 Tamże.

6 B. Nierenberg, Na to, żeby komuś odebrać wolność, musi być sąd. Reportaże, Wydawnictwo Uniwersytetu Jagiellońskiego, Kraków 2016, s. 5.

7 A. Modzelewska, Struktury organizacyjne NSZZ „Solidarnośc” w latach 1980-1989, Wydawnictwo Uniwersytetu Jagiellońskiego, Kraków 2019. 
Jak wspomniałem, najwięcej jest książek obierających historyczną perspektywę badawczą. Dotyczy to zarówno publikacji polskich, jak i obcojęzycznych. Wśród nich istotne wydają się praca Timothy'ego Gartona Asha The Polish Revolution: Solidarity ${ }^{8}$ oraz prawie tak samo obszerna Ryszarda Terleckiego Solidarność 19801989. Polska droga do wolności $i^{9}$. W tym miejscu trzeba podkreślić, jak ważną rolę $\mathrm{w}$ dokumentowaniu najnowszej historii Polski odgrywa Instytut Pamięci Narodowej, w tym także tych związanych z Solidarnością. Mimo rozmaitych zastrzeżeń, które nie są przedmiotem rozważań niniejszego artykułu, należy docenić trud naukowy i publikacyjny wielu badaczy współpracujących z IPN-em. Dotyczy to zwłaszcza autorów i redaktorów wielotomowego, monumentalnego dzieła Encyklopedia Solidarności $i^{10}$. Do tego należy dodać szereg publikacji dokumentujących w sposób mniej lub bardziej szczegółowy rozmaite aspekty walki o niepodległość, których edytorami są poszczególne oddziały IPN. Przykładem jest dzieło zatytułowane Komunistyczny aparat represji i życie społeczne Opolszczyzny w latach 19451989 pod redakcją Ksawerego Jasiaka, którego rozdział napisany przez Zbigniewa Bereszyńskiego, a zatytułowany Służba Bezpieczeństwa i media informacyjne w województwie opolskim stał się dla mnie istotną motywacją, by sięgnąć do własnych doświadczeń związanych $\mathrm{z}$ dążeniami niepodległościowymi ${ }^{11}$.

Jeśli idzie o literaturę związaną z Solidarnością, to należałoby wskazać na jej historyczno-socjologiczne ujęcie Bronisława Misztala w książce Poland after Solidarity: Social Movements versus the State ${ }^{12}$, która została opublikowana jeszcze przed upadkiem komunizmu w Polsce. Jej autor przedstawił swoje diagnozy i oceny już w 1984 roku na konferencji w Pitzer College.

Rzadkością są badania i publikacje odnoszące się do kulturowych następstw rewolucji solidarnościowej. Do takich należałoby zaliczyć Michaela D. Kennedy’ego Cultural Formations of Postcommunism: Emancipation, Transition, Nation and War ${ }^{13}$, choć trzeba dodać, że dzieło to zawiera nie tylko wyniki badań nad kulturowymi następstwami gwałtownych zmian, jakie nastąpiły po upadku komunizmu w naszej części Europy, ale też odnosi się do napięć społecznych i ekonomicznych towarzyszących przejściu od gospodarki centralnie planowanej do gospodarki rynkowej.

8 T.G. Ash, The Polish Revolution: Solidarity, Yale University Press, New Haven 2002.

9 R. Terlecki, Solidarność 1980-1989. Polska droga do wolności, Wydawnictwo AA, Kraków 2018.

10 Encyklopedia Solidarności, t. 1-3, red. M. Łątkowska, G. Waligóra, J. Olaszek i in., Wydawnictwo Instytutu Pamięci Narodowej, Warszawa 2010-2019. Druk tomu czwartego planowany jest na 2020 rok.

11 Z. Bereszyński, wskazując na działania NSZZ „Solidarność” w Radiu Opole, wielokrotnie przywołuje nazwisko autora niniejszego artykułu; por. Z. Bereszyński, Służba Bezpieczeństwa i media informacyjne w województwie opolskim, [w:] Komunistyczny aparat represji i życie społeczne Opolszczyzny w latach 1945-1989. Studia i materiały, red. K. Jasiak, Oddział Instytutu Pamięci Narodowej - Komisja Ścigania Zbrodni przeciwko Narodowi Polskiemu we Wrocławiu, Wrocław 2012, s. 187-189, 193-197, 234, 251, 262.

12 Por. B. Misztal, Poland after Solidarity: Social Movements versus the State, Transaction Publisher, New Brunswick 1985.

13 Por. M.D. Kennedy, Cultural Formations of Postcommunism: Emancipation, Transition, Nation and War, University of Minnesota Press, Minneapolis 2002. 
Istotnym źródłem wiedzy i możliwością konfrontacji moich własnych wspomnień jest wymieniona już praca Anny Modzelewskiej. Autorka ukazuje w niej struktury NSZZ „Solidarność” w rozmaitych okresach działalności - od 1980 aż po rok 1989. Jej badania pokazują między innymi, iż ojcowie założyciele Solidarności zdawali sobie sprawę, że ich inteligenckość będzie wadą, a nie zaletą w zderzeniu z machiną komunistycznej dyktatury, opartej na micie „robotnika sprawującego władzę" ${ }^{14}$. Stąd decyzja, by na czele związku stanął robotnik, a nie inteligent. Dla komunistycznej władzy i głoszonej przez nią ideologii stanowiło to twardy orzech do zgryzienia. Tymczasem w poszczególnych regionach bywało różnie. Na przykład na Opolszczyźnie - której dotyczą zdarzenia opisane w niniejszym artykule - zastosowano wariant mieszany. Dwaj pierwsi przewodniczący Zarządu Regionu Solidarności: Bogusław Bardon ${ }^{15}$ i Roman Kirstein ${ }^{16}$ mają korzenie robotnicze, ale ten trzeci, Stanisław Jałowiecki, legitymuje się doktoratem z socjologii, obronionym na Uniwersytecie Jagiellońskim ${ }^{17}$.

Należy też zauważyć, że praca A. Modzelewskiej badająca struktury organizacyjne Solidarności jest dziełem na swój sposób unikatowym, na co zwrócił uwagę Andrzej Gwiazda obecny podczas obrony jej dysertacji ${ }^{18}$. Unikatowość ta polega głównie na tym, że na polskim gruncie jest to pierwsza dysertacja w obszarze nauk o zarząazzaniu, która podejmuje temat skuteczności struktur organizacyjnych stworzonych przez Solidarność w latach 1980-1989. Nie znam podobnych badań prowadzonych w Europie i na świecie. Poczytuję sobie za honor, że mogłem przyczynić się do jej powstania ${ }^{19}$.

\section{Metodologia}

Metodologia zastosowana w niniejszym artykule jest rodzajem kompromisu badawczego i wymaga kilku słów objaśnienia, rzadko bowiem udaje się znaleźć uniwersalny klucz, który otwiera wszystkie zamki. Tak jest i tym razem. Dominującym narzędziem do realizacji założonego celu badawczego jest autoetnografia. Michał Zawadzki zasadnie wskazuje, że jest to metoda, która „umożliwia badaczowi pogłębione zrozumienie procesów zachodzących w konkretnym kontekście społeczno-kulturowym

14 Propaganda komunistyczna głosiła mit o przodującej roli klasy robotniczej.

15 Encyklopedia Solidarności, http://www.encysol.pl/wiki/Bogusław_Bardon (dostęp: 30.12.2019).

16 Wikipedia, https://pl.wikipedia.org/wiki/Roman_Kirstein (dostęp: 30.12.2019).

17 Wikipedia, https://pl.wikipedia.org/wiki/Stanisław_Jałowiecki (dostęp: 30.12.2019).

18 Andrzej Gwiazda, jedna z legend Solidarności, podczas publicznej obrony (9 marca $2018 \mathrm{r}$. w Auli Collegium Novum Uniwersytetu Jagiellońskiego) powiedział, iż „nie spodziewał się, że po rozmaitych głupstwach, które czynił IPN, ratunek dla Solidarności przyjdzie ze strony Wydziału Zarządzania Uniwersytetu Jagiellońskiego" (cytuję z pamięci, więc słowa i ich szyk mógł być nieco inny, ale taki był ich sens).

19 Byłem promotorem dysertacji doktorskiej A. Modzelewskiej. 
poprzez osadzenie indywidualnej biografii w tym kontekście i dzięki doświadczeniu $\mathrm{z}$ innymi aktorami społecznymi” ${ }^{20}$. Ten sam autor wskazuje na istotność wykorzystania w narracji wątków osobistych czy wręcz osobistego eseju.

Dla takiego sposobu eksploracji badacz winien być członkiem badanej grupy, ergo: winien być zarówno uczestnikiem, jak i obserwatorem ${ }^{21}$. Byłem uczestnikiem tamtych zdarzeń, ale czy dziś, po 40 latach mam prawo nazywać się obserwatorem. Na ile moje dzisiejsze „obserwacje” odpowiadają opisywanym faktom, a na ile moje późniejsze życie weryfikowało i zmieniało moją pamięć i opis zdarzeń sprzed 40 lat? Tę wątpliwość mogłaby rozwiać triangulacja, zaczerpnięta na przy$\mathrm{kład} \mathrm{z}$ teorii ugruntowanej ${ }^{22}$. Nie jest moim zamiarem formułowanie jakiejkolwiek teorii, bowiem przy autoetnografii byłoby o to trudno. Moim zamiarem jest jedynie taka weryfikacja opisu, by spełniał on kryteria naukowości. Barney G. Glaser i Anselm L. Strauss wskazują na kilka rodzajów triangulacji, spośród których istotna jest (w przypadku niniejszego artykułu) triangulacja metodologiczna ${ }^{23}$. Polega ona na wykorzystaniu rozmaitych metod badawczych, w tym przypadku byłyby to: wywiady, obserwacje, analizy dokumentów ${ }^{24}$. Do tego dodałbym debatę $z$ innymi badaczami oraz świadkami opisywanych zdarzeń, która pozwala je skonfrontować z własnym obrazem zdarzeń, zachowanym w pamięci.

Do takiej konfrontacji doszło w sierpniu 2019 roku, kiedy to zostałem zaproszony do udziału w seminarium „Porozumienia sierpniowe - prasowe echa i rzeczywiste odgłosy”, które zorganizowało Centrum Dialogu Społecznego w Opolu. Początkowo chciałem się wykręcić od udziału w tej debacie. Uważałem, że to raczej zadanie dla historyków niż osób, które jak ja zajmują się zarządzaniem organizacjami medialnymi. Jednak prawie 40 lat temu pracowałem w redakcji literackiej Polskiego Radia w Opolu i byłem świadkiem tamtych zdarzeń na Opolszczyźnie. W niektórych nawet aktywnie uczestniczyłem ${ }^{25}$. Zatem mój udział we wspomnianej debacie dawał mi szansę na zweryfikowanie obrazów tamtego czasu, które zachowała moja pamięć.

Moje dociekania w tym obszarze dotykają także antropologii organizacji w takim rozumieniu, w jakim prezentowali je Alfred Radcliffe-Brown i Bronisław Malinowski ${ }^{26}$, a etnografii organizacji $\mathrm{w}$ takim rozumieniu, jakie prezentują Barbara

20 M. Zawadzki, Autoetnografia, [w:] Metody badawcze w zarzadzaniu humanistycznym, red. M. Kostera, Wydawnictwo Akademickie Sedno, Warszawa 2015, s. 61.

${ }^{21}$ L. Anderson, Analytic Autoethnography, "Journal of Contemporary Ethnography” 2006, nr 35(5), s. 373-380.

22 Por. B.G. Glaser, A.L. Strauss, The Discovery of Grounded Theory: Strategies for Qualitative Research, Aldine Transaction, New Brunswick 1967.

23 Tamże.

24 T. Ludwicki, Teoria ugruntowana, [w:] Metody badawcze w zarzadzaniu humanistycznym, red. M. Kostera, Wydawnictwo Akademickie Sedno, Warszawa 2015, s. 43.

25 W latach 1980-1981 do NSZZ „Solidarność” w Radiu Opole należało jedynie czworo dziennikarzy, jednym z nich był autor niniejszego artykułu (por. Z. Bereszyński, dz. cyt., s. 251).

26 Por. A. Radcliffe-Brown, Wyspiarze z Andamanów. Studia $z$ antropologii społecznej, Wydawnictwo Marek Derewiecki, Kęty 2006; B. Malinowski, Wolność i cywilizacja oraz Studia z pogranicza antropologii społecznej, ideologii i polityki, Wydawnictwo Naukowe PWN, Warszawa 2001. 
Czarniawska i Monika Kostera ${ }^{27}$. Mam też moje własne rozumienie tych pojęć, które wynika z moich wcześniejszych dociekań badawczych ${ }^{28}$.

Korzystałem także z analizy dokumentów zgromadzonych podczas karnawału Solidarności w latach $1980-1981^{29}$ oraz audycji radiowych, które w owym czasie zrealizowałem. Dokonałem analizy dokumentów i wywiadów sprzed lat, w tym dwóch wywiadów nieustrukturyzowanych, $\mathrm{z}$ których zwłaszcza jeden, ten $\mathrm{z}$ marca 1981 roku ze Stanisławem Jałowieckim, ówczesnym przewodniczącym Zarządu Regionu Solidarności Śląska Opolskiego, wydaje się szczególnie użyteczny z punktu widzenia prowadzonych badań oraz zastosowanej metodologii, bowiem w zamyśle autora miał być on jedynie materiałem archiwalnym.

I wreszcie ostatnia $\mathrm{z}$ zastosowanych metod badawczych: studium przypadku. Krzysztof Obłój i Aleksandra Wąsowska piszą, że w naukach o zarządzaniu konkretny przypadek służy do „opisu, wyjaśnienia oraz uogólnienia pewnego szczególnego zjawiska" ${ }^{30}$. Badacz rozpoznaje eksplorowany przypadek poprzez wywiady $\mathrm{z}$ respondentami, którzy są aktorami opowieści. Rolą badacza jest taka interpretacja zebranego materiału, by wzbogacał on naszą wiedzę o danym obszarze rzeczywistości $\mathrm{i}^{31}$. Dane $\mathrm{z}$ wywiadów winny być uzupełnione dodatkowo pozyskanymi informacjami, co służy triangulacji zarówno metod badawczych, jak i otrzymanych wyników. W tym przypadku jest to cokolwiek trudne, gdyż głównym celem tego artykułu nie są ani fakty, ani ich chronologia, lecz emocje towarzyszące danym zdarzeniom. W podsumowaniu odnoszę się także do faktów, ale widzianych przez okulary emocji. Widać to zwłaszcza, kiedy żądania natury finansowej, artykułowane podczas strajków, przeradzają się w postulaty dotyczące godności i solidarności z drugim człowiekiem. Można to również dostrzec w postawach dziennikarzy zatrudnionych w reżimowych mediach. Przyzwoitość nakazuje opowiedzieć się po stronie prawdy, ale czasami brakowało odwagi, a czasami właśnie przyzwoitości. Bo przecież przywódcy struktur związkowych NSZZ „Solidarność”, i to na różnych szczeblach, to tylko ludzie. Czy cechuje ich chłodna kalkulacja, jak daleko można się posunąć w żądaniach wobec komunistycznej władzy, a na ile ich postulaty i działania są efektem ówczesnych emocji? Mam oczywiście świadomość, że po tylu latach trudno o jednoznaczne odpowiedzi. Dotyczy to także mnie jako badacza, nie da się bowiem z chirurgiczną precyzją oddzielić tego, co myślałem wów-

27 Por. B. Czarniawska, Trochę inna teoria organizacji. Organizowanie jako konstrukcja sieci działań, Wydawnictwo Poltext, Warszawa 2010; M. Kostera, Antropologia organizacji. Metodologia badań terenowych, Wydawnictwo Naukowe PWN, Warszawa 2005.

28 Por. M. Popiołek, B. Nierenberg, Facebook as an information management tool - in light of research conducted among Polish students, „Journal of Education Culture and Society” 2017, nr 2.

29 Większość z posiadanych przeze mnie pamiątek z lat 1980-1981 przekazałem do Izby Pamięci Solidarności otwartej 4 czerwca 2019 roku w 30. rocznicę pamiętnych polskich wyborów; Izba mieści się w Opolu przy ul. Damrota 1

${ }_{30}$ K. Obłój, A. Wąsowska, Studium przypadku, [w:] Metody badawcze w zarządzaniu humanistycznym, s. 51.

31 Tamże. 
czas, od tego, co wiem dziś. Niemniej jednak podjąłem próbę odtworzeni tamtych zdarzeń i tamtych emocji, które nam, Polakom, wtedy towarzyszyły.

\section{Konstrukcja}

Kwestie dotyczące konstrukcji niniejszego artykułu objaśniłem poniekąd w uwagach wstępnych oraz części poświęconej zagadnieniom metodologicznym. W sensie formalnym konstrukcja naukowa mojego tekstu jest niejednorodna, co wynika z heterogeniczności nauk o zarządzaniu.

Jest to rodzaj eseju naukowego opartego na materiałach źródłowych, obserwacjach, autoetnografii oraz studiach przypadku. Jednak jego istota nie sprowadza się do historycznego ułożenia faktów, a raczej odtwarzania emocji, które towarzyszyły tamtym wydarzeniom. Taka na przykład jest rozmowa z socjologiem, dr. Stanisławem Jałowieckim, nagrana w siedzibie Zarządu Regionalnego opolskiej Solidarności późnym wieczorem, a może nawet w nocy (mój ówczesny rozmówca też tego nie pamięta). To nagranie miało (chyba) raczej charakter archiwalny, ale - co podkreślę raz jeszcze - dobrze oddaje emocje, które towarzyszyły wielu z nas wiosną 1981 roku. Jałowiecki zastąpił na stanowisku przewodniczącego Zarządu Regionu NSZZ „Solidarność” Śląska Opolskiego Romana Kirsteina. I to jemu przyszło podjąć próbę kontynuowania działalności związkowej po ogłoszeniu stanu wojennego ${ }^{32}$.

\section{Studia przypadku - eksplikacja}

Pierwszy przypadek będzie dotyczyć pierwszego (bądź jednego z pierwszych) strajku na Śląsku Opolskim, który odbył się w Rejonowym Przedsiębiorstwie Gospodarki Komunalnej i Mieszkaniowej w Nysie. Oficjalnie zaczął się 2 września 1980 roku. Trwał 10 dni i zakończył się podpisaniem porozumienia płacowego, choć w istocie postulaty strajkowe zgłoszono już 30 sierpnia 1980 roku, czyli w przeddzień podpisania porozumień sierpniowych.

Drugie studium to materiał pochodzący z audycji z 11 listopada 1980 roku, zachowany w archiwum Radia Opole dzięki pracownikowi taśmoteki, Jerzemu Poznańskiemu, który nie wykonał polecenia służbowego i nie skasował tzw. szpiega ${ }^{33}$. A kiedy rozpoczął się stan wojenny, schował pudełko z audycją za nieczynnym kaloryferem.

I wreszcie trzecie nagranie to moja na poły prywatna rozmowa z dr. Stanisławem Jałowieckim. Jego istota odnosi się do pobicia działaczy Solidarności, w tym

32 S. Jałowiecki, Refleksje z podziemia, druk ulotny wydany nakładem Zarządu Regionu NSZZ „Solidarność” Śląska Opolskiego, Opole 2019.

${ }_{33}$ W żargonie radiowym mianem szpiega określa się taśmę z nagraniem danej audycji, najczęściej emitowanej na żywo na wypadek ewentualnych kontrowersji lub procesu sądowego. 
Jana Rulewskiego, Mariusza Łabentowicza i Michała Bartoszcze, co wydarzyło się 16 marca 1981 roku w Bydgoszczy. Skutkiem tych zajść był czterogodzinny strajk ostrzegawczy przeprowadzony 27 marca 1981 roku. Gdyby nie doszło do porozumienia z komunistyczną władzą w trakcie prowadzonych negocjacji, 31 marca 1981 roku miał się odbyć strajk generalny, proklamowany w całym kraju.

W tych trzech studiach przypadku, które pragnę poddać analizie, dobrze widoczny jest nastrój i konsekwencje porozumień sierpniowych. Ponadto wydało mi się, że słowa wypowiedziane podczas wzmiankowanej debaty są ulotne i w zasadzie nie pozostaje po nich żaden ślad, poza lakonicznymi informacjami w lokalnych mediach. A oprócz tego tamte wydarzenia $\mathrm{z}$ lat 1980-1981 to jeden $\mathrm{z}$ najważniejszych okresów w naszej dwudziestowiecznej historii. Zatem świadectwa tamtego czasu, niekoniecznie świadectwa historyczne, mają istotną wartość dla zrozumienia naszej polskiej przeszłości.

\section{Studium przypadku I: strajk w Nysie}

Jak już wspomniałem, strajk w Rejonowym Przedsiębiorstwie Gospodarki Komunalnej i Mieszkaniowej w Nysie oficjalnie zaczął się w poniedziałek, 2 września 1980 roku, choć postulaty pracownicze zostały zgłoszone już w piątek, 30 sierpnia. Nie ulega wątpliwości, że stan wrzenia w całym kraju był efektem tego, co działo się w Gdańsku. Była to zachęta do walki o swoje prawa, co dla wielu oznaczało wyższe pensje. Kierownik działu w RPGKiM w Nysie, jeden z bohaterów reportażu Anatomia strajku, mówi o tych postulatach tak:

Więc oni po prostu zaprogramowali te swoje postulaty i się pod nimi musieli podpisać, więc musieli utworzyć komitet strajkowy. Ale już w sobotę ta emocja była większa, bo w komunikacji miejskiej dowiedzieli się, że mechanicy dostali po 24 zł na godzinę, a nasi mieli po 18 zł na godzinę. I tam dostali podwyżki, u nas nie i stąd zapowiedzieli, że we wtorek godz. 10.00 strajk, jeżeli przedsiębiorstwo nie spełni tych postulatów ${ }^{34}$.

Wydaje się, że gra toczyła się jedynie o to, by wyrwać, co swoje, a reszta protestujących nie interesowała. Nic bardziej mylnego. Wówczas słowo „solidarność" zaczęło nabierać właściwych treści. Wielu powoli uświadamiało sobie, że to rodzaj gry, w której albo wygramy wszyscy, albo wszyscy polegniemy. Dobrze oddają to słowa robotnika, jednego z uczestników strajku:

Dyrekcja zaproponowała mechanikom przejść do zakładów higieny komunalnej ze stawką $21 \mathrm{zł}+30$ procent premii, to daje w sumie na godzinę $5 \mathrm{zł} 10 \mathrm{gr}$., z tym że pomijając, powiedzmy, sprawy kierowców. Mechanicy tę propozycję mogliby przyjąć, jeżeliby były uregulowane sprawy kierowców, sprawy płacowe. Ale mechanicy dalej się jednak solidaryzują z kierowcami, nie skorzystali z tej propozycji ${ }^{35}$.

34 B. Nierenberg, Na to, żeby komuś odebrać wolność, musi być sąd, s. 161.

35 Tamże, s. 162-163. 
Przedstawiciele Komitetu Strajkowego RPGKiM w Nysie sformułowali w sumie 10 postulatów: dziewięć dotyczyło warunków pracy, ostatni, a raczej pierwszy - podwyżki płac. Względem tych dziewięciu punktów przedstawiciele dyrekcji i strajkujących porozumieli się już we wtorek 2 września. Pozostał ostatni, postulat płacowy. Dyrektor Wołoszczyk popierał swoich pracowników, bo wiedział, że w innych zakładach mają tabele $\mathrm{z}$ wyższymi stawkami. Jednak nowe tabele płac dla każdego przedsiębiorstwa musiało w owym czasie zatwierdzić zjednoczenie, ale nie mogło tego uczynić bez zgody resortu, czyli stosownego ministerstwa. Taka procedura trwała 10 dni i dobrze obrazowała niewydolność gospodarki centralnie sterowanej. Koniec końców dyrektor Jankowski ze Zjednoczenia przywiózł osobiście do Nysy teleks z ministerialną akceptacją nowych tabel płacowych i w półtorej godziny podpisano porozumienie. Załoga wróciła do pracy.

\section{Studium przypadku II: 63. rocznica odzyskania niepodległości}

11 listopada 1980 roku byłem autorem audycji porannej w Radiu Opole, emitowanej na żywo. Zaprosiłem do niej ówczesnego dr. Stanisława Nicieję ${ }^{36}$. Wprawdzie trwał karnawał Solidarności, ale władza komunistyczna wciąż miała się dobrze, a za wschodnią granicą uważnie przyglądał się nam Wielki Brat.

Pamiętam jednak to uczucie - moje i części koleżanek i kolegów - że na antenie Polskiego Radia znowu możemy mówić o naszym święcie narodowym, które komuniści wyrzucili z panteonu rocznic. Tu uwaga istotna dla osób niezaznajomionych z funkcjonowaniem radia. Cały program był nagrywany na tzw. szpiegu, czyli taśmie, która była obowiązkowo przechowywana przez 30 dni. Dziś zresztą jest tak samo, na wypadek ewentualnych procesów sądowych. Wtedy „szpieg” pełnił zupełnie inną funkcję. Mówiąc bez ogródek: szpiegował poczynania dziennikarzy, na wypadek gdyby się im powiedziało coś niemiłego dla władzy.

Zatem jest 11 listopada 1980 roku. Pytam Nicieję jako historyka o przebieg zdarzeń, które przywróciły nam wolność po 123 latach niewoli, i w pewnej chwili mówię coś takiego:

(...) mnie z tą rocznicą kojarzy się taka książka z mojego dzieciństwa. Nazywała się chyba Henryś Benedykta Hertza i tam bohater tej książki traci ojca i odzyskuje go właśnie w roku 1918, w sposób wręcz cudowny, który jak gdyby go nobilitował w oczach otoczenia, mianowicie jego ojciec wraca z Legionami, właśnie z tymi sławnymi Legionami. I właściwie dla większości Polaków, bo historia jakoś tak prześlizgiwała się po tym temacie, nie bardzo chętnie mówiliśmy o tej rocznicy, szczególnie w tym powojennym trzydziestosześcioleciu, i większości z nas właściwie ta rocznica niepodległości kojarzyła się z Piłsudskim i z Legionami ${ }^{37}$.

36 Ówczesny dr Stanisław Nicieja jest od wielu lat profesorem tytularnym; był też w latach 19962002 oraz 2005-2008 rektorem Uniwersytetu Opolskiego.

37 B. Nierenberg, Na to, żeby komuś odebrać wolność, musi być sąd, s. 149. 
Na te słowa dr Nicieja odpowiada tak:

(...) ja jestem zupełnie zaskoczony jako historyk. Mam co prawda pewien dar przewidywania, natomiast zaskoczony jestem, że dzisiaj w tej Polsce, w której żyjemy, są te obchody państwowe rocznicy odzyskania niepodległości. Do tej pory ta sprawa była przemilczana i dochodziło nawet do sytuacji groteskowych i tragicznych dla narodu, że jak ktoś obchodził tę rocznicę, to był szykanowany. Natomiast rozdmuchiwało się inne rocznice. Słuszne, sensowne, na przykład rocznicę rewolucji październikowej, ale bez rocznicy odzyskania niepodległości, owe obchody tamtej rocznicy były szkodliwe dla przyjaźni polsko-radzieckiej. Jeżeli mamy poważnie mówić o historii, poważnie mówić o tym, co minęło, to musimy pokazywać i tę rocznicę, i tę, i czcić je obie, tak jak na to obie zasługują ${ }^{38}$.

W tym momencie przeleciało mi przez głowę, czy naczelny już szykuje mi zwolnienie, czy jeszcze mi odpuści, bo Nicieja był poza jego zasięgiem. Ale pomyślałem sobie: a co tam, warto było dożyć takiej chwili. Miałem wtedy 40 lat mniej. Piękny wiek! A w takim wieku fascynują człowieka rozmaite rzeczy, w tym na przykład fenomen Piłsudskiego, więc zapytałem:

(...) czemu należy właściwie zawdzięczać, że to akurat wokół osoby Piłsudskiego skoncentrował się naród? Bo przecież sam mówił Pan przed chwilą, że tych orientacji przeróżnych politycznych było bardzo wiele. Tworzyły się przeróżne, przedziwne rządy, koalicje i zjawia się Piłsudski, który potrafi to skupić w jednym ręku i stworzyć jeden rząd narodowy. Rząd, wokół którego skupia się cały naród ${ }^{39}$.

Na co dr Nicieja odpowiedział tak:

Piłsudski miał w sobie charyzmę, która jest przynależna mężom stanu i wybitnym indywidualnościom. To był człowiek, który potrafił fascynować nie tylko masy, ale potrafił skutecznie oddziaływać na różne orientacje polityczne. I zasługą bezsprzeczną Piłsudskiego jest to, że w tym trudnym momencie potrafił się wznieść nad tzw. partyjniactwo. To znaczy: społeczeństwo polskie było zawsze pluralistyczne, rozbite na dziesiątki różnych stronnictw, organizacji i wiele partii. I te partie ze sobą walczyły, próbowały formować swoje programy, swoje koncepcje. Piłsudski też był „partyjniakiem”, można powiedzieć, bo był członkiem PPS-u, później mu się zarzucało, że wysiadł z czerwonego tramwaju na przystanku niepodległość i w innym kierunku pojechał. (...) On to rozumiał i świadomie do tego zmierzał, w pewnym momencie odchodzi od koncepcji lansowania tylko koncepcji PPS-owskich, żeby znaleźć szeroką bazę, bo wiedział, że musi się dogadać i z burżuazją, i z magnaterią, arystokracją, rządami klasowymi, i z ludowcami, którzy byli potężną siłą, i z chadekami, i z endekami, że musi na tej płaszczyźnie tworzyć państwo, bo gdyby tej platformy nie zrobil, to państwo się rozleci, znaczy państwo nigdy nie powstanie.

Tak jak możemy to powiedzieć na przykładach innych sąsiadów, choćby takich ośrodków władzy na Ukrainie, w tym czasie się natworzyło wiele. I co z tego? Nie doszło do połączenia i wiemy, że to państwo miało wielkie problemy z odzyskaniem niepodległości i wciąż ma problemy $y^{40}$.

\footnotetext{
38 Tamże.

39 Tamże, s. 150-151.

40 Tamże.
} 
Jeżeli do tej pory mogłem sobie imaginować, że jednak zachowam pracę w radiu, to po tym, co powiedział dr Nicieja, straciłem wszelką nadzieję. Naczelny musi mnie wyrzucić, bo inaczej wyrzucą jego. Moja audycja kwestionowała niepodległość Ukrainy - „jednego z krajów Związku Radzieckiego”. Dr Nicieja powiedział prawdę, ale co z tego.

I tu stała się rzecz niezwykła. Wszyscy nabrali wody w usta, tak jakby tej audycji w ogóle nie było. Redaktor naczelny polecił pracownikowi archiwum radiowego skasować „szpiega” z tym trefnym nagraniem. Jednak dzielny Jurek Poznański tego polecenia nie wykonał, a w stanie wojennym schował pudełko z nagraniem za nieczynnym kaloryferem.

\section{Studium przypadku III: przygotowania do strajku ostrzegawczego i generalnego na Opolszczyźnie po wydarzeniach bydgoskich}

Dr. Stanisława Jałowieckiego poznałem w drugiej połowie lat 70. Był wówczas pracownikiem Instytutu Śląskiego. Zaprzyjaźniliśmy się. Staszek był częstym gościem moich audycji. Jako socjolog wskazywał na rozmaite patologie tamtego czasu (fucha, lapówkarstwo etc.). Także to nagranie (niestety we fragmentach) przetrwało $\mathrm{w}$ archiwum opolskiego radia dzięki postawie jego pracownika, Jerzego Poznańskiego, który schował pudełko z taśmą za nieczynnym kaloryferem. Rozmowa ma na poły prywatny charakter, choć obaj czuliśmy podskórnie, że dotyczy zdarzeń historycznych. I tak było w istocie, bowiem po pobiciu w Bydgoszczy znanych działaczy Solidarność ogłosiła strajk ostrzegawczy w całym kraju. Gdyby nie przyniósł on spodziewanych efektów, miał zostać zarządzony strajk generalny.

Rozmowa zaczyna się od smętnej refleksji, że mimo podwyższonej gotowości przed strajkiem ostrzegawczym Jałowiecki bez problemu wszedł w nocy z czwartku na piątek (z 26 na 27 marca 1980 r.) do siedziby MKZ w Opolu przy ul. Reymonta. Potem następuje opis euforii po udanym piątkowym strajku ostrzegawczym, który zdaniem Jałowieckiego był zasługą poszczególnych załóg, a nie działań organizacyjnych MKZ. W najbliższych wtorek, 31 marca 1980 roku, miał się rozpocząć strajk generalny. Należało się spodziewać kontrdziałań komunistycznych władz. Jałowiecki opisuje to tak:

Umówiliśmy się na piątek na spotkanie do MKZ-u. Mieliśmy przygotować specjalny numer „Solidarności”, postrajkowy, ale wiem, że Jarek ${ }^{41}$ już w tym momencie miał jakieś chytre plany. Chciał doprowadzić koniecznie do rozmowy takiej sztabowej z Kirszteinem. Rozmowy, która by się zakończyła podjęciem jakiejś decyzji co do funkcjonowania MKZ-u, co do najlepszego przygotowania do tego strajku powszechnego. I takie plany mogły być, ale ja do końca sobie $\mathrm{z}$ tego sprawy nie zdawałem, że to jest wszystko aż tak groźne. Oczywiście spotkaliśmy się wieczorem w redakcji i znów to, co uderzyło nas

${ }^{41}$ „Jarek” - Jarosław Chołodecki, wiceprzewodniczący ZR „S”. 
wcześniej - że jest to znowu bezhołowie, że jakieś takie typy różne tam krążą, że to wszystko jest takie jakieś niekontrolowane, informacja jest niekontrolowana, nie jest czytany serwis, nie ma czytania teleksów.

Doszło do takiego spotkania w piątek w nocy, gdzieś chyba koło $12.00 \mathrm{w}$ nocy. Spotkanie zakończyło się zupełnie nieoczekiwanie. Kirsztein namówiony do tej rozmowy zaczął się gwałtownie zastanawiać nad tym, czy to jest dobry pomysł. Doszedł do wniosku, że w takich warunkach pracować nie może. Czynnikiem ostatecznym, który o tym przesądził, był taki fakt, że złapał bezpośrednio jednego z pracowników na kontakcie z SB. Doszedł do wniosku, że nie może pracować w takich warunkach, kiedy są bez przerwy donosy i są relacje tego, co się dzieje, tu wewnątrz, w MKZ. Kirstein słyszał konfidenta rozmawiającego przez telefon i było jeszcze jakieś tam nagranie, które dodatkowo uzyskał. Tak że były dwa takie dowody. Był w stu procentach pewny, że on jest współpracownikiem SB, i to spowodowało, że rzeczywiście skłaniał się do podjęcia decyzji o wyjeździe. (...)

Było kilka punktów wytypowanych tej ewentualnej ewakuacji. Jednym z tych punktów był punkt w Ozimku, drugim punktem ZNTK, trzeci był w Prudniku, ale nie podjęto decyzji o przeniesieniu się i prawdopodobnie gdyby nie ten fakt, fakt ujawnienia tego agenta czy konfidenta, to Kirsztein by się na to nie zdecydował. I gdyby nie ten nacisk, głównie Jarka, na podjęcie pewnych decyzji, jakichkolwiek decyzji, byle decyzji. Bo tak dłużej być nie może, takie bezhołowie, to taka decyzja nie zostałaby podjęta.

Decyzja została podjęta następująca. Zadzwonił on [Kirstein] do Prudnika, do Foryst$\mathrm{ka}^{42}$, do MKZ Ziemi Prudnickiej, który wcześniej przygotowywał teren w Prudniku i przygotowywał ewakuację MKZ-u opolskiego do Prudnika. Forystek przyjechał w nocy i właśnie w nocy odbyliśmy taką sztabową rozmowę. Rozmowy, w których były normalne sprawy: jakie zabezpieczenia tego MKZ-u w tym Frotexie, jakie są systemy zabezpieczające, czy jest możliwość robienia jakiegoś kolportażu, czy jest możliwość łączników, można coś tam drukować, powielać, czy jest spanie, jedzenie, tego typu powiedzmy sprawy.

No, nie przewidywaliśmy wtedy czynnika, który okazał się być istotny dla oceny, mianowicie, że to jest tak daleko i może to być odbierane przez ludzi w kategoriach ucieczki do Prudnika ${ }^{43}$.

Jeżeli ktoś jest ciekaw personalnych przepychanek „kto ważniejszy”, „kto za co odpowiada” - to odsyłam do lektury książki $N a$ to, żeby komuś odebrać wolność, musi być sąd. O wiele ważniejszy był w owym czasie stan umysłów i emocje. Jałowiecki opisał to tak:

Nakręcaliśmy się wszyscy. Nakręcaliśmy się, że ten strajk jednak będzie. Nie dopuszczaliśmy do siebie myśli, że może nie być. Nie chcieliśmy osłabiać swojego, że tak powiem, morale strajkowego. Staraliśmy się wierzyć, że ten strajk dojdzie do skutku, a my musimy go dobrze przygotować. Toteż umacnialiśmy się ciągle w tym przekonaniu, mimo że były różne głosy zwątpienia poszczególnych ludzi. Rozmawialiśmy z ludźmi z Frotexu. Rzadko bo rzadko, ale jednak. Wyczuwaliśmy te obawy ludzi. Co będzie? Jaki będzie ten strajk? Jak to się wszystko potoczy? Czy wkroczą Rosjanie, czy nie wkroczą? Czy będzie wojna domowa, czy stan wyjątkowy? Jak to się wszystko potoczy? Takie niepokoje do nas dochodziły, ale $\mathrm{z}$ drugiej strony mieliśmy taki biegun ekstremalny. Biegun złożony z takich ekstremistów.

42 „Forystek” - Jakub Forystek, inicjator utworzenia MKZ „S” Ziemi Prudnickiej

43 B. Nierenberg, Na to, żeby komuś odebrać wolność, musi być sąd, s. 174-176. 
To była cała ekipa Frotexu, cały komitet Frotexu i Ziemi Prudnickiej. Chłopcy, którzy byli zdecydowani na wszystko. Gotowi już chyba dla samego strajku, no, polec ${ }^{44}$.

W nocy z niedzieli na poniedziałek, czyli z 29 na 30 marca 1980 roku, we Frotexie nie śpią. Pewnie w innych miejscach także. W opisie Jałowieckiego tak to wygląda:

Zaczęło się od tych teleksów dotyczących prawa zajmowania przez Solidarność różnych gmachów publicznych. To były teleksy, które były wpuszczane w siatkę przez agencję TASS, że Solidarność zajmuje jakieś tam instytucje, że poczty zajmuje. Zauważono nawet jakichś facetów $\mathrm{z}$ bronią $\mathrm{w}$ ręku, że są napady na posterunki milicji. Sporo takich właśnie informacji, które potem były dementowane. W międzyczasie zaczęły hulać informacje Krajowej Komisji Porozumiewawczej. Między innymi jedna informacja, która jakby potwierdziła moje wcześniejsze obawy, to znaczy informacja, że rozmowy Solidarności z rządem muszą być przerwane o godzinie 14.15. Wiadomo, że te rozmowy były wyznaczone na poniedziałek o godzinie 14.15, tak żeby jeszcze o 15.00, o której to godzinie mijał właściwie termin, mijała możliwość odłożenia lub odwieszenia strajku, żeby można się było jakoś telefonicznie skontaktować z członkami Krajowej Komisji Porozumiewawczej, tak żeby coś tam jeszcze zawiesić, odwiesić, coś z tym strajkiem zrobić. Jak tak się stało, wiedzieliśmy, że o godzinie 14.15 rozmowy nie zostaną przedłużone, to mamy strajk na pewno. A praktycznie rzecz biorąc, to strajk jest już o godzinie 9.00 , bo posłuchać całą komisję byłoby bardzo trudno przed godziną 9.00 . Tak że właściwie o godzinie 9.00 rano możemy się przygotować do strajku i na dobrą sprawę nie ma możliwości jego odwołania zgodnie z zaleceniami KKP. No, przygotowaliśmy [się] ostro już do tego wszystkiego. Przygotowaliśmy serwis informacyjny, sprawdzaliśmy jeszcze tam jakieś możliwości informowania się z poszczególnymi innymi MKZ. Przygotowaliśmy się do spotkania z posłami, które się miało odbyć w poniedziałek. Wysłaliśmy wcześniej informację, że to spotkanie może się odbyć tylko we Frotexie, ponieważ wyjechaliśmy do Frotexu, do Prudnika. Spotkanie się nie odbyło, bo okazało się potem, że posłowie nie chcieli przyjechać do Prudnika. Pojawili się na spotkaniu w Opolu.

Potem był poniedziałek. Poniedziałek, w którym zaczęły napływać wiadomości co najmniej dwoma kanałami. Pierwszy kanał to był Reymont ${ }^{45}$, który nie wytrzymywał napięcia i zaczęły się jakieś zaskakujące wydarzenia tam dziać. Ludzie zaczęli po prostu uciekać z MKZ, z Reymonta. Zaczęli uciekać i zamiast uciekać ewentualnie do swoich zakładów pracy, do wytypowanych, do tych, w których mieli się schronić, to uciekali gdzieś. Chronili się po prostu po mieście. A inni ludzie, a część została w tym MKZ, ale była podszyta tak grubym strachem, że co chwila wysyłali do nas informacje, czy mają zostać, czy nie mają zostać. Co mają w tym MKZ właściwie robić? Jednocześnie widać było, że napięcie społeczne sięga już maksymalnych granic. Przychodziły informacje o rozmowach między Solidarnością a rządem. Rozmowy, które pierwotnie były takimi, no, dość nieoptymistycznymi. Nie wiadomo, czy to porozumienie się w ogóle... Aha, no była ta noc plenum, kiedy szaleńcze informacje napływały siatką teleksową, bo na przykład napływały informacje, że całe plenum podało się do dymisji. Cały Komitet Centralny podał się do dymisji in corpore, dosłownie. Potem ta informacja zastała sprostowana. (...) Więc była to noc, w której się te wszystkie rzeczy komasowały. Gęstniało. Jednocześnie wisiała groźba wkroczenia wojsk radzieckich, bez przerwy wisiało to ${ }^{46}$.

44 Tamże, s. 186.

45 Przy ulicy Reymonta mieściła się siedziba MKZ Opole.

46 B. Nierenberg, Na to, żeby komuś odebrać wolność, musi być sąd, s. 187-189. 
Kiedy we Frotexie napięcie sięga zenitu, do Prudnika przyjeżdża z Opola jeden z członków zarządu NSZZ „Solidarność” Śląska Opolskiego. I znowu opis Jałowieckiego:

W międzyczasie przyjechał Wiktor ${ }^{47}$ z Polmozbytu i jak zobaczył, że my tu jesteśmy wszyscy napaleni na strajk i że właściwe wszyscy chcą robić strajk, zaczął nam uświadamiać, że przecież nastrój opinii społecznej zupełnie inny, że wszyscy nie chcą tego strajku, że będą czekać nawet do 6.00 rano, byleby tego strajku nie było. Obwołaliśmy go defetystą, że nie nasze jest takie. Tu tylko i wyłącznie przygotowywać strajk i znamy takie odczucia społeczne, ale mimo wszystko my nie możemy być defetystami. Możemy się przygotowywać na najgorszą możliwość. Ale właśnie od czasu do czasu takie informacje do nas dopływały, że to, że tamto. Wreszcie czekanie bez przerwy przy telewizorze na wyniki rozmów.

Kiedy dowiedzieliśmy się, że jest przesunięty termin odwołania strajku z godziny 15.00 na 20.00 i kiedy Kirstein dostał informację, że od godziny 18.00 do 20.00 czuwać przy telefonie na ewentualną informację o tym, co KKP, znaczy właściwe nie tyle KKP, ile Wałęsa i ta grupa negocjatorów zadecydowała, to wiedzieliśmy, że już praktycznie tego strajku nie będzie. To przesunięcie spowodowało, że atmosfera, napięcie społeczne klapło natychmiast. Ludzie wiedzieli, że natychmiast, przynajmniej ci wtajemniczani w tryby tej machiny strajkowej, że napięcie opadnie i nie będzie szans na przywrócenie tego napięcia z powrotem do poprzedniego stanu, że to musi oznaczać załamanie już tego wszystkiego. Kirsztein się właściwie cieszył. Cieszył, że tak się stało. On do końca czekał na taką właśnie decyzję. Już nie wchodził, że są jakieś formalne niepoprawności w tym wszystkim, że to są jakieś złamania reguł gry. Cieszył się.

Ja byłem wściekły. Byłem wściekły. Zupełnie to pozbawia argumentów grupę Wałęsy w dalszych godzinach negocjacji do godziny 19.00. Że takie rozwiązanie między godziną 15.00 a 19.00 wytrąca im zupełnie broń z ręki. I to, co zadecydowało w tych czterech godzinach, to się zadecydowało tak, jak później oczywiście, że ten kompromis był kompromisem no w sumie kiepskim dla Solidarności. To te cztery godziny zadecydowały. Godziny, w których oni złamali własne reguły gry. Tym samym dali potworny argument rządowi do ręki, który pozwalał wynegocjować to, co właściwie można były wynegocjować, a co okazało się jednak pewną porażką w skali samych porozumień, dla samej Solidarności ${ }^{48}$.

Takie emocje towarzyszyły wtedy działaczom Solidarności, ale też wielu milionom Polaków, którzy zwyczajnie bali się o swój los. Nie jest moim zadaniem oceniać tamtych zdarzeń. Chciałem jedynie przypomnieć ówczesne emocje, które przesądzały nie tylko o losie wielu Polaków, ale też determinowały kształtowanie się struktur prawdziwie niezależnej organizacji, jaką był w owym czasie Niezależny Samorządny Związek Zawodowy „Solidarność”.

47 Włodzimierz Wiktor - członek Zarządu NSZZ „Solidarność” Śląska Opolskiego, pracownik opolskiego Polmozbytu.

48 B. Nierenberg, Na to, żeby komuś odebrać wolność, musi być sąd, s. 189-190. 


\section{Podsumowanie}

Wydaje się, że niniejsza analiza oparta na trzech studiach przypadku uprawnia mnie do wysnucia następujących wniosków:

1. Początkowo efektem porozumień sierpniowych były głównie postulaty płacowe, mniej polityczne. Jednak w owym czasie słowo „solidarność" nabiera swego właściwego wymiaru (vide: słowa robotnika w reportażu Anatomia strajku).

2. Porozumienia sierpniowe dały niektórym mediom i dziennikarzom możliwość, by mówić o sprawach, które wcześniej były nieobecne w dyskursie publicznym. Jednak opis zdarzeń zależał już nie tylko od cenzury, ale również od sumienności i rzetelności poszczególnych dziennikarzy, mimo że działali w strukturach mediów będących pod kontrolą partii komunistycznej.

3. Analiza źródłowa materiałów dziennikarskich pozwala zrozumieć emocje, które towarzyszyły wydarzeniom z lat 1980-1981. Te emocje przekładały się nie tylko na sposób postrzegania ówczesnej rzeczywistości, ale także warunkowały funkcjonowanie struktur, w jakich działali (vide: rozmowa $\mathrm{z}$ S. Jałowieckim).

Jestem przekonany, że zaprezentowany materiał badawczy oraz moje refleksje dotyczące opisywanych zdarzeń wzbogacają wiedzę o jakże ważnych dla naszej historii i tożsamości narodowej momentach. Zmierzenie się (w sensie naukowym, ale i w wymiarze zwyczajnych ludzkich emocji) z tym obszarem rzeczywistości przekonuje mnie, że trzeba i warto badać wszystko, co wiąże się z Solidarnością w najróżniejszych ujęciach i rozmaitych polach badawczych.

Są takie chwile w życiu narodów, ale i struktur, w jakich działają, kiedy nad wyraz istotna staje się postawa ludzi wobec zdarzeń i innych osób. Ten stan dobrze opisują słowa sprzed prawie tysiąca lat. Wypowiedział je w XI wieku Bernard z Chartres:

Jesteśmy jak karły, które wspinają się na ramiona gigantów, by widzieć więcej od nich i da-

lej sięgać wzrokiem, i to nie za sprawą bystrości swojego wzroku czy wysokości ciała, lecz dzięki temu, że wspinamy się w górę i wznosimy na wysokość gigantów ${ }^{49}$.

Ta myśl opisuje nie tylko wielkich herosów, którzy w momentach przełomowych stają na czele całych narodów, ale też i takich jak mój krajan Roman Kirstein, który kierował regionalną Solidarnością na Opolszczyźnie ${ }^{50}$. Pomimo upływu lat żywię do niego wielki szacunek za przymioty umysłu i serca, dzięki którym starał się ludzi łączyć, a nie dzielić. Warto również pamiętać, że za sprawą takich właśnie "gigantów” jak Kirstein możemy dziś „widzieć więcej i dalej sięgać wzrokiem”. Oby nasza zbiorowa mądrość w tym względzie pozwoliła nam, Polakom, pamiętać, że nic nie jest dane na wieki, że o wolność naszej ojczyzny trzeba nieustająco zabiegać.

49 S. Swieżawski, Dzieje europejskiej filozofii klasycznej, Wydawnictwo Naukowe PWN, Warszawa-Wrocław 2000, s. 486.

50 Staraniem Romana Kirsteina została w Opolu otwarta izba upamiętniająca opolską Solidarność. Stało się to 4 czerwca 2019 roku, trzy miesiące po śmierci jej pomysłodawcy. 
Dbać o nią, chronić, by nikt nam jej nie odebrał. Nie są to słowa ani pompatyczne, ani na wyrost. Moje stosunkowo długie życie nauczyło mnie, że najtrudniej jest pamiętać o prawdach oczywistych.

\section{Bibliografia}

Anderson L., Analytic Autoethnography, „Journal of Contemporary Ethnography” 2006, nr 35(5).

Ash T.G., The Polish Revolution: Solidarity, Yale University Press, New Haven 2002.

Bereszyński Z., Stużba Bezpieczeństwa i media informacyjne w województwie opolskim, [w:] Komunistyczny aparat represji i życie społeczne Opolszczyzny w latach 1945-1989. Studia i materiały, red. K. Jasiak, Oddział Instytutu Pamięci Narodowej - Komisja Ścigania Zbrodni przeciwko Narodowi Polskiemu we Wrocławiu, Wrocław 2012.

Czarniawska B., Trochę inna teoria organizacji. Organizowanie jako konstrukcja sieci działań, Wydawnictwo Poltext, Warszawa 2010.

Encyklopedia Solidarności, t. 1, red. Ł. Kamiński, Wydawnictwo Instytutu Pamięci Narodowej, Warszawa 2010.

Encyklopedia Solidarności, t. 2, red. M. Łątkowska, G. Waligóra, J. Olaszek i in., Wydawnictwo Instytutu Pamięci Narodowej, Warszawa 2012.

Encyklopedia Solidarności, t. 3, red. M. Łątkowska, G. Waligóra, J. Olaszek i in., Wydawnictwo Instytutu Pamięci Narodowej, Warszawa 2019.

Etnografia organizacji. Badania polskich firm i instytucji, red. nauk. M. Kostera, Gdańskie Wydawnictwo Psychologiczne, Sopot 2011.

Glaser B.G., Strauss A.L., The Discovery of Grounded Theory: Strategies for Qualitative Research, Aldine Transaction, New Brunswick 1967.

Jałowiecki S., Refleksje z podziemia, druk ulotny wydany nakładem Zarządu Regionu NSZZ „Solidarnośćc Śląska Opolskiego, Opole 2019.

Kennedy M.D., Cultural Formations of Postcommunism: Emancipation, Transition, Nation and War, University of Minnesota Press, Minneapolis 2002.

Komunistyczny aparat represji i życie społeczne Opolszczyzny w latach 1945-1989. Studia i materiały, red. K. Jasiak, Oddział Instytutu Pamięci Narodowej - Komisja Ścigania Zbrodni przeciwko Narodowi Polskiemu we Wrocławiu, Wrocław 2012.

Kostera M., Antropologia organizacji. Metodologia badań terenowych, Wydawnictwo Naukowe PWN, Warszawa 2005.

Ludwicki T., Teoria ugruntowana, [w:] Metody badawcze w zarzadzaniu humanistycznym, red. M. Kostera, Wydawnictwo Akademickie Sedno, Warszawa 2015.

Magala S.J., Kompetencje międzykulturowe, Oficyna Wolters Kluwer, Warszawa 2011.

Malinowski B., Studia z pogranicza antropologii społecznej, ideologii i polityki, Wydawnictwo Naukowe PWN, Warszawa 2001.

Malinowski B., Wolność i cywilizacja, Wydawnictwo Naukowe PWN, Warszawa 2001.

Metody badawcze w zarządzaniu humanistycznym, red. M. Kostera, Wydawnictwo Akademickie Sedno, Warszawa 2015.

Misztal B., Poland after Solidarity: Social Movements versus the State, Transaction Publisher, New Brunswick 1985.

Modzelewska A., Struktury organizacyjne NSZZ „Solidarność” w latach 1980-1989, Wydawnictwo Uniwersytetu Jagiellońskiego, Kraków 2019. 
Nierenberg B., Na to, żeby komuś odebrać wolność, musi być sąd. Reportaże, Wydawnictwo Uniwersytetu Jagiellońskiego, Kraków 2016.

Obłój K., Wąsowska A., Studium przypadku, [w:] Metody badawcze w zarządzaniu humanistycznym, red. M. Kostera, Wydawnictwo Akademickie Sedno, Warszawa 2015.

Popiołek M., Nierenberg B., Facebook as an information management tool - in light of research conducted among polish students, „Journal of Education Culture and Society” 2017, nr 2.

Radcliffe-Brown A., Wyspiarze z Andamanów. Studia $z$ antropologii społecznej, Wydawnictwo Marek Derewiecki, Kęty 2006.

Swieżawski S., Dzieje europejskiej filozofii klasycznej, Wydawnictwo Naukowe PWN, Warszawa-Wrocław 2000.

Terlecki R., Solidarność 1980-1989. Polska droga do wolności, Wydawnictwo AA, Kraków 2018.

\section{Netografia}

Encyklopedia Solidarności, http://www.encysol.pl/wiki/Bogusław_Bardon.

Wikicytaty, https://pl.wikiquote.org/wiki/Stefan_Kisielewski.

Wikipedia, https://pl.wikipedia.org/wiki/Wydawnictwo_podziemne.

Wikipedia, https://pl.wikipedia.org/wiki/Roman_Kirstein.

Wikipedia, https://pl.wikipedia.org/wiki/Stanisław_Jałowiecki.

wPolityce.pl, https://wpolityce.pl/historia/281194-40-lat-temu-uchwalono-poprawki-do-konstytucji-prl-wprowadzajac-zapis-o-przyjazni-z-zsrr. 